\title{
Data report: clay mineral assemblages in cuttings from Hole C0002N, IODP Expedition 348, Nankai Trough accretionary prism ${ }^{1}$
}

Michael B. Underwood ${ }^{2}$

\section{Chapter contents}

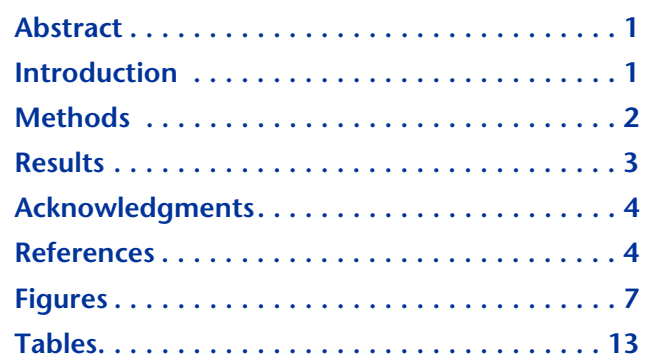

'Underwood, M.B., 2017. Data report: clay mineral assemblages in cuttings from Hole C0002N, IODP Expedition 348, Nankai Trough accretionary prism. In Tobin, H., Hirose, T., Saffer, D., Toczko, S., Maeda, L., Kubo, Y., and the Expedition 348 Scientists, Proceedings of the Integrated Ocean Drilling Program, 348: College Station, TX (Integrated Ocean Drilling Program). doi:10.2204/iodp.proc.348.203.2017

2Department of Earth and Environmental Science, New Mexico Institute of Mining and Technology, Socorro New Mexico 87801, USA.

UnderwoodM@missouri.edu

\section{Abstract}

This report summarizes the results of X-ray diffraction analyses of cuttings samples (1-4 mm diameter) from Integrated Ocean Drilling Program Hole C0002N, which is located offshore southwest Japan. The analyses included 73 specimens $(<2 \mu \mathrm{m}$ size fraction) from the upper to middle levels of the Nankai accretionary prism. The cuttings were collected over a depth interval of 1175 to 2305 meters below seafloor (mbsf). Smectite is generally the most abundant clay mineral. Within lithologic Unit IV, percentages of smectite in the bulk sediment average $25.5 \mathrm{wt} \%$ (standard deviation = 5.7), whereas values for illite and undifferentiated kaolinite + chlorite average 19.5 and $11.9 \mathrm{wt} \%$, respectively (standard deviations $=2.3$ and 1.9). Within lithologic Unit $\mathrm{V}$, percentages of smectite in the bulk sediment decrease to an average of $21.4 \mathrm{wt} \%$ (standard deviation $=2.1$ ); mean values of illite and kaolinite + chlorite are 21.6 and $14.9 \mathrm{wt} \%$, respectively (standard deviations $=2.1$ and 2.5). The expandability of illite/smectite averages $64 \%$, and values decrease downsection. The average proportion of illite in illite/smectite mixed-layer clays is $35 \%$, and values increase downsection. The illite crystallinity index shifts at approximately 1495 mbsf; values above are consistent with detrital sources that were exposed to advanced diagenesis and anchizone metamorphic conditions; values below are smaller (higher apparent crystallinity) due to an analytical artifact.

\section{Introduction}

Scientific ocean drilling has sampled the Nankai Trough offshore southwest Japan (Fig. F1) numerous times over the past four decades (Karig, Ingle, et al., 1975; Kagami, Karig, Coulbourn, et al., 1986; Shipboard Scientific Party, 1991; Shipboard Scientific Party, 2001; Moore et al., 2005). The Nankai Trough Seismogenic Zone Experiment (NanTroSEIZE) is the latest of those efforts (Ashi et al., 2009; Screaton et al., 2009; Tobin et al., 2009; Underwood et al., 2010; Expedition 333 Scientists, 2012; Strasser et al., 2014a; see the "Expedition 348 summary" chapter [Tobin et al., 2015a]). Integrated Ocean Drilling Program (IODP) Site C0002 is located on the NanTroSEIZE transect near the seaward edge of the Kumano Basin (Fig. F1). Expedition 348 deepened the holes at Site C0002 by riser drilling into the middle accretionary prism (Fig. F2), reaching a record depth of 3058 meters below seafloor (mbsf) 
(see the "Expedition 348 summary" chapter [Tobin et al., 2015a]). The common lithology in cuttings is clayey siltstone (hemipelagic mudstone), with variable percentages of medium silt to fine sand (turbidites). A lithologic boundary occurs at 1665 mbsf in Hole C0002N and is defined by a sharp reduction of sandstone content (Fig. F3). During Expedition 338 (Strasser et al., 2014a), that same boundary in Hole C0002F was placed at 1740 mbsf (Fig. F3).

This report summarizes the results of X-ray diffraction (XRD) analyses of 73 cuttings samples (1-4 mm) extracted from Hole C0002N. Previous investigators demonstrated that hemipelagic mud(stones) throughout the Nankai region change in composition largely as function of depositional age (Cook et al., 1975; Chamley, 1980; Chamley et al., 1986; Underwood et al., 1993a, 1993b; Steurer and Underwood, 2003; Underwood and Steurer, 2003; Guo and Underwood, 2012; Underwood and Guo, 2013). The cuttings from Hole C0002N contain nannofossils that are late Miocene (>5.59 Ma) in age (see the "Site C0002" chapter [Tobin et al., 2015b]). As a rule, mud deposited near Nankai Trough during the Miocene was enriched in expandable clay (smectite group), whereas proportions of detrital illite and chlorite increased steadily during the Pliocene and Quaternary. The primary objective of this report is to show whether or not samples from Hole C0002N conform to that temporal trend. Another fundamental goal of NanTroSEIZE is to document the diagenetic and hydration states of clay minerals (especially the smectite group) within accreted and subducting Nankai strata (i.e., subduction inputs). That task is important because of the clay's likely influence on fluid production within the accretionary prism and along the landward-dipping plate interface (e.g., Saffer et al., 2008). This report also includes characterization of clay mineral diagenesis over the depth range of Hole C0002N.

The drilling technology during Expedition 338 obscured the stratigraphic details of Hole C0002F by placing a $12^{1 / 4}$ inch drill bit at the base of the bottom hole assembly and a 20 inch reamer bit above the logging tools. That configuration of two cutting tools resulted in thorough mixing of cuttings over a vertical interval of at least $43.8 \mathrm{~m}$ (Strasser et al., 2014a). Hole C0002N was drilled without the reamer bit, so the vertical extent of mixing was reduced considerably. A third objective of this report is to assess how those differences in mixing might have affected compositional data, through a direct comparison among data from equivalent depths in Holes C0002F and C0002N.

\section{Methods}

\section{Sample preparation}

All of the samples analyzed in this study were selected from cuttings measuring 1-4 mm in effective diameter (concentrated shipboard by wet sieving). Each extracted interval of cuttings included a companion specimen for shipboard bulk-powder XRD; those scans provided estimates of the relative abundance of total clay minerals, quartz, feldspar, and calcite (Strasser et al., 2014b; see the "Site C0002" chapter [Tobin et al., 2015b]). Isolation of the claysize fraction for XRD analyses started with air drying and gentle hand-crushing of the mudstone with mortar and pestle, after which specimens were immersed in $3 \% \mathrm{H}_{2} \mathrm{O}_{2}$ for at least $24 \mathrm{~h}$ to digest organic matter. After adding $250 \mathrm{~mL}$ of Na-hexametaphosphate solution (concentration of $4 \mathrm{~g} / 1000 \mathrm{~mL}$ distilled $\mathrm{H}_{2} \mathrm{O}$ ), the beakers were inserted into an ultrasonic bath for several minutes to promote disaggregation and deflocculation. After visual confirmation of disaggregation, samples were washed by two passes through a centrifuge (8200 revolutions per minute [rpm] for $25 \mathrm{~min}$; $6000 \mathrm{~g}$ ) with resuspension in distilled-deionized water after each pass. The suspended sediment was then transferred to a 60 $\mathrm{mL}$ plastic bottle and resuspended by vigorous shaking and a 2 min application of an ultrasonic cell probe. The clay-size splits $(<2 \mu \mathrm{m}$ equivalent settling diameter) were separated by centrifugation (1000 rpm for $2.4 \mathrm{~min} ; \sim 320 \mathrm{~g}$ ). Preparation of oriented clay aggregates followed the filter-peel method (Moore and Reynolds, 1989a) using $0.45 \mu \mathrm{m}$ filter membranes. To saturate expandable clay minerals with ethylene glycol, slides were transferred to a closed vapor chamber and heated to $60^{\circ} \mathrm{C}$ for at least $24 \mathrm{~h}$ prior to XRD analysis.

\section{X-ray diffraction}

Expedition 348 cuttings samples were analyzed at the New Mexico Bureau of Geology and Mineral Resources using a Panalytical X'Pert Pro diffractometer with $\mathrm{Cu}$ anode. Scans of oriented clay aggregates were run at generator settings of $45 \mathrm{kV}$ and $40 \mathrm{~mA}$. The continuous scans cover an angular range of $3^{\circ}$ to $26.5^{\circ} 2 \theta$, with scan step time of $1.6 \mathrm{~s}$, step size of $0.01^{\circ} 2 \theta$, and the sample holder spinning. Slits are 1.0 $\mathrm{mm}$ (divergence) and $0.1 \mathrm{~mm}$ (receiving). MacDiff software (version 4.2.5) was used to establish a baseline of intensity, smooth counts, correct peak positions offset by misalignment of the detector (using the quartz $(100)$ peak at $20.95^{\circ} 2 \theta$; d-value $=4.24 \AA$ ), and calculate integrated peak areas (total counts). 
This program also calculates peak width at half height. A glitch in this procedure was created by a move of the X-ray diffractometer to a new building at New Mexico Tech; technicians from Panalytical mistakenly installed a $15 \mathrm{~mm}$ mask rather than the $20 \mathrm{~mm}$ mask that had been used previously. That switch reduced the area of the X-ray beam, which resulted in lower peak intensities and smaller dimensions of peak width at half height. The switch occurred after scanning cuttings samples 65 through 134 and before scanning samples 138 through 323 .

\section{Calculations of mineral abundance}

The most accurate analytical methods for XRD analyses require calibration with internal standards, use of single-line reference intensity ratios, and some fairly elaborate sample preparation steps to create ideal random particle orientations (e.g., Srodon et al., 2001; Omotoso et al., 2006). Given the unusually large number of samples to analyze throughout the NanTroSEIZE project, our strategy has been to obtain reliable semiquantitative accuracy with optimal efficiency. To accomplish that for the clay-size fraction, we recorded the integrated areas of a broad smectite (001) peak centered at $\sim 5.3^{\circ} 2 \theta(\mathrm{d}$-value $=16.5 \AA)$, the illite (001) peak at $\sim 8.9^{\circ} 2 \theta(\mathrm{d}$-value $=9.9 \AA)$, the composite peak of chlorite (002) + kaolinite (001) at $12.5^{\circ} 2 \theta$ (d-value $\left.=7.06 \AA\right)$, and the quartz (100) peak at $20.85^{\circ} 2 \theta(\mathrm{d}$-value $=4.26 \AA)$.

Underwood et al. (2003) describe how mineral standards are analyzed to calculate a matrix of singular value decomposition (SVD) normalization factors (Table T1). The mixtures for those standards consist of smectite + illite + chlorite + quartz. The average errors (measured weight percent versus computed weight percent) are $3.9 \%$ for smectite, $1.0 \%$ for illite, $1.9 \%$ for chlorite, and $1.6 \%$ for quartz. The chlorite (002) and kaolinite (001) peaks overlap almost completely. A refined version of the Biscaye (1964) method (see Guo and Underwood, 2011) allows separation between the kaolinite (002) and chlorite (004) peaks. The average error of accuracy for the chlorite/kaolinite ratio is $2.6 \%$, and that ratio was used to compute individual mineral percentages from the undifferentiated weight percent of chlorite (002) + kaolinite (001). To calculate the abundance of individual clay minerals as weight percent in the bulk mudstone, we multiply each relative percentage value among the clay minerals (where smectite + illite + chlorite + kaolinite $=100 \%$ ) by the percentage of total clay minerals within the bulk powder (where total clay minerals + quartz + feldspar + calcite $=$ $100 \%$ ), as determined by shipboard XRD analyses of collocated specimens (Strasser et al., 2014b; see the "Site C0002" chapter [Tobin et al., 2015b]). To facili- tate direct comparisons with other published data sets from the region, this report also includes the weighted peak area percentages for smectite, illite, and undifferentiated chlorite + kaolinite as computed by Biscaye (1965) weighting factors $[1 \times$ smectite (001), $4 \times$ illite (001), and $2 \times$ chlorite $(002)+$ kaolinite (001)]. Errors of accuracy using that method are usually substantially greater $( \pm 10 \%$ or more) than errors using SVD normalization factors (Underwood et al., 2003).

For documentation of clay diagenesis, the saddle/ peak method of Rettke (1981) was used to calculate percent expandability of smectite and illite/smectite (I/S) mixed-layer clay. This method is sensitive to the proportions of discrete illite (I) versus I/S mixed-layer clay; the curve for 1:1 mixtures of I and I/S provides the best match for the range of Nankai specimens. A complementary measure of the proportion of illite in the I/S mixed-layer phase is based on the $2 \theta$ angle of the $(002 / 003)$ peak (following Moore and Reynolds, $1989 b$ ). We use the quartz (100) peak to correct peak position for misalignment of the detector and/or sample holder. The I/S (002/003) peak tends to be broad and low in intensity, so the center of the peak needs to be picked manually. Values of illite crystallinity (Kübler) index are reported here as peak width at half height $\left(\Delta^{\circ} 2 \theta\right)$ for the (001) reflection.

\section{Results}

Table T2 shows the peak-area values (total counts) for common minerals in the clay-size fraction, separated by lithologic unit. Table T2 also includes the weight percent values of mineral abundance calculated via SVD normalization factors and the weighted peak-area percentages using Biscaye (1965) factors. Relative abundances of clay-size smectite within lithologic Unit IV range from 53 to $28 \mathrm{wt} \%$ (Fig. F4), with a mean value $(\mu)$ of 41.7 wt $\%$ and a standard deviation $(\sigma)$ of 7.1. Values for illite in the clay-size fraction range from 39 to $27 \mathrm{wt} \%(\mu=32.3$; $\sigma=3.2$ ). Percentages of undifferentiated kaolinite + chlorite in Unit IV range from 24 to $15 \mathrm{wt} \%(\mu=$ 19.6; $\sigma=2.6$ ); in all cases, chlorite is the dominant mineral over kaolinite. Percentages of clay-size quartz average $3.9 \mathrm{wt} \%(\sigma=4.2)$. Within Unit $\mathrm{V}$, the values for clay-size smectite range from 42 to $27 \mathrm{wt} \%$ $(\mu=33.5 ; \sigma=3.7)$. Abundances of illite range from 45 to $27 \mathrm{wt} \%(\mu=33.8 ; \sigma=4.0)$, whereas the content of kaolinite + chlorite ranges from 27 to $17 \mathrm{wt} \%(\mu=$ $23.2 ; \sigma=2.9)$. The average percentage of clay-size quartz is $6.1 \mathrm{wt} \%(\sigma=3.1)$. Comparable values from Hole C0002F (Underwood and Song, 2016) show no systematic offsets or changes in scatter relative to the results from C0002N (Fig. F4). 
Figure F5 illustrates how relative mineral abundances change within the bulk sediment as a function of depth. Within Unit IV, bulk-sediment smectite ranges from 35 to $11 \mathrm{wt} \%(\mu=25.5, \sigma=5.7)$. Most of those percentages are significantly lower than what Underwood and Guo (2013) documented at Sites C0011 and C0012 in the Shikoku Basin (i.e., the Nankai subduction inputs) (Fig. F1), where coeval (5 to $6 \mathrm{Ma}$ ) Miocene strata contain averages of 30 to $33 \mathrm{wt} \%$ smectite. Illite in the bulk sediment of Unit IV ranges from 25 to $15 \mathrm{wt} \%(\mu=19.5, \sigma=2.3)$, and the amount of kaolinite + chlorite ranges from 16 to $8 \mathrm{wt} \%(\mu=11.9, \sigma=1.9)$. Within lithologic Unit $\mathrm{V}$, the abundance of bulk-sediment smectite is reduced more, ranging from 27 to $17 \mathrm{wt} \%(\mu=21.4$, $\sigma=2.1)$. Illite in the bulk sediment ranges from 27 to $15 \mathrm{wt} \%(\mu=21.6 ; \sigma=2.1)$, and kaolinite + chlorite ranges from 20 to $10 \mathrm{wt} \%(\mu=14.9 ; \sigma=2.5)$. As with the clay-size fraction, parallel plots of the bulk-sediment values from Hole C0002F (Underwood and Song, 2016) show no systematic offsets or changes in scatter relative to results from similar depths in C0002N (Fig. F5). Thus, it appears as though compositional data for Site $\mathrm{C0002}$ have not been affected by the expanded and contracted vertical intervals over which cuttings were mixed within the respective boreholes.

Indicators of clay diagenesis are tabulated in Table T3 and plotted as a function of depth in Figure F6. Values of the illite crystallinity (Kübler) index range from 0.62 to $0.25 \Delta^{\circ} 2 \theta$; the average value is $0.36 \Delta^{\circ} 2 \theta$. As a frame of reference, the boundary between advanced diagenesis and anchizone metamorphism is set at $0.52 \Delta^{\circ} 2 \theta$, and the achizone-epizone boundary (incipient greenschist facies) is $0.32 \Delta^{\circ} 2 \theta$ (Warr and Mählmann, 2015). A pronounced shift toward an apparent enhancement of clay crystallinity (narrower peak width) in Hole C0002N is found at about 1495 mbsf, and a mismatch occurs below that depth between values from C0002F and C0002N (Fig. F6). That shift, however, is probably an artifact of having different masks installed on the diffractometer, as described in "Methods". The expandability of illite/ smectite mixed-layer clays ranges from 89 to $59 \%$. The average value is $64 \%(\sigma=2.1)$, and expandability decreases with increasing depth (Fig. F6). The proportion of illite in illite/smectite mixed-layer clays ranges from 16 to $53 \%$, with an average value of $35 \%$ $(\sigma=7.9)$. Those values are scattered, but the proportion of illite in I/S increases as depth increases (Fig. F6).

\section{Acknowledgments}

This research used samples provided by the Integrated Ocean Drilling Program (IODP). We thank the Mantle Quest Japan drilling crew, Marine Works Japan laboratory technicians, and scientists aboard the $\mathrm{D} / \mathrm{V}$ Chikyu for their dedicated assistance during IODP Expedition 348. Funding was granted by the Consortium for Ocean Leadership, U.S. Science Support Program (task order T348B58). Nolan Walla and Chen Song assisted with sample preparation. Jun Kameda provided a review of the manuscript.

\section{References}

Ashi, J., Lallemant, S., Masago, H., and the Expedition 315 Scientists, 2009. Expedition 315 summary. In Kinoshita, M., Tobin, H., Ashi, J., Kimura, G., Lallemant, S., Screaton, E.J., Curewitz, D., Masago, H., Moe, K.T., and the Expedition 314/315/316 Scientists, Proceedings of the Integrated Ocean Drilling Program, 314/315/316: Washington, DC (Integrated Ocean Drilling Program Management International, Inc.). http://dx.doi.org/ 10.2204/iodp.proc.314315316.121.2009

Biscaye, P.E., 1964. Distinction between kaolinite and chlorite in recent sediments by X-ray diffraction. American Mineralogist, 49:1281-1289. http://www.minsocam.org/ammin/AM49/AM49_1281.pdf

Biscaye, P.E., 1965. Mineralogy and sedimentation of recent deep-sea clay in the Atlantic Ocean and adjacent seas and oceans. Geological Society of America Bulletin, 76(7):803-831. http://dx.doi.org/10.1130/00167606(1965)76[803:MASORD]2.0.CO;2

Chamley, H., 1980. Clay sedimentation and paleoenvironment in the Shikoku Basin since the middle Miocene (Deep Sea Drilling Project Leg 58, North Philippine Sea). In Klein, G. de V., Kobayashi, K., et al., Initial Reports of the Deep Sea Drilling Project, 58: Washington, DC (U.S. Govt. Printing Office), 669-678. http://dx.doi.org/10.2973/dsdp.proc.58.118.1980

Chamley, H., Cadet, J.-P., and Charvet, J., 1986. Nankai Trough and Japan Trench late Cenozoic paleoenvironments deduced from clay mineralogic data. In Kagami, H., Karig, D.E., Coulbourn, W.T., et al., Initial Reports of the Deep Sea Drilling Project, 87: Washington, DC (U.S. Govt. Printing Office), 633-641. http:// dx.doi.org/10.2973/dsdp.proc.87.113.1986

Cook, H.E., Zemmels, I., and Matti, J.C., 1975. X-ray mineralogy data, far western Pacific, Leg 31 Deep Sea Drilling Project. In Karig, D.E., Ingle, J.C., Jr., et al., Initial Reports of the Deep Sea Drilling Project, 31: Washington (U.S. Govt. Printing Office), 883-895. http:// dx.doi.org/10.2973/dsdp.proc.31.app.1975 
Expedition 333 Scientists, 2012. Expedition 333 summary. In Henry, P., Kanamatsu, T., Moe, K., and the Expedition 333 Scientists, Proceedings of the Integrated Ocean Drilling Program, 333: Tokyo (Integrated Ocean Drilling Program Management International, Inc.). http://dx.doi.org/ 10.2204/iodp.proc.333.101.2012

Guo, J., and Underwood, M.B., 2011. Data report: refined method for calculating percentages of kaolinite and chlorite from X-ray diffraction data, with application to the Nankai margin of southwest Japan. In Kinoshita, M., Tobin, H., Ashi, J., Kimura, G., Lallemant, S., Screaton, E.J., Curewitz, D., Masago, H., Moe, K.T., and the Expedition 314/315/316 Scientists, Proceedings of the Integrated Ocean Drilling Program, 314/315/316: Washington, DC (Integrated Ocean Drilling Program Management International, Inc.). http://dx.doi.org/ 10.2204/iodp.proc.314315316.201.2011

Guo, J., and Underwood, M.B., 2012. Data report: clay mineral assemblages from the Nankai Trough accretionary prism and the Kumano Basin, IODP Expeditions 315 and 316, NanTroSEIZE Stage 1. In Kinoshita, M., Tobin, H., Ashi, J., Kimura, G., Lallemant, S., Screaton, E.J., Curewitz, D., Masago, H., Moe, K.T., and the Expedition 314/315/316 Scientists, Proceedings of the Integrated Ocean Drilling Program, 314/315/316: Washington, DC (Integrated Ocean Drilling Program Management International, Inc.). http://dx.doi.org/10.2204/ iodp.proc.314315316.202.2012

Kagami, H., Karig, D.E., Coulbourn, W.T., et al., 1986. Initial Reports of the Deep Sea Drilling Project, 87: Washington, DC (U.S. Govt. Printing Office). http://dx.doi.org/ 10.2973/dsdp.proc.87.1986

Karig, D.E., Ingle, J.C., Jr., et al., 1975. Initial Reports of the Deep Sea Drilling Project, 31: Washington, DC (U.S. Govt. Printing Office). http://dx.doi.org/10.2973/ dsdp.proc.31.1975

Moore, D.M., and Reynolds, R.C., Jr., 1989a. Sample preparation techniques for clay minerals. In Moore, D.M., and Reynolds, R.C., Jr. (Eds.), X-Ray Diffraction and the Identification and Analysis of Clay Minerals: New York (Oxford University Press USA), 179-201.

Moore, D.M., and Reynolds, R.C., Jr., 1989b. Identification of mixed-layered clay minerals. In Moore, D.M., and Reynolds, R.C., Jr. (Eds.), X-Ray Diffraction and the Identification and Analysis of Clay Minerals: New York (Oxford Univ. Press USA), 241-271.

Moore, G.F., Mikada, H., Moore, J.C., Becker, K., and Taira, A. 2005. Legs 190 and 196 synthesis: deformation and fluid flow processes in the Nankai Trough accretionary prism. In Mikada, H., Moore, G.F., Taira, A., Becker, K., Moore, J.C., and Klaus, A. (Eds.), Proceedings of the Ocean Drilling Program, Scientific Results, 190/196: College Station, TX (Ocean Drilling Program), 1-25. http:// dx.doi.org/10.2973/odp.proc.sr.190196.201.2005

Omotoso, O., McCarty, D.K., Hillier, S., and Kleeberg, R., 2006. Some successful approaches to quantitative mineral analysis as revealed by the 3rd Reynolds Cup contest. Clays and Clay Minerals, 54(6):748-760. http:// dx.doi.org/10.1346/CCMN.2006.0540609
Rettke, R.C., 1981. Probable burial diagenetic and provenance effects on Dakota Group clay mineralogy, Denver Basin. Journal of Sedimentary Petrology, 51(2):541-551. http://dx.doi.org/10.1306/212F7CCF-2B24-11D78648000102C1865D

Saffer, D.M., Underwood, M.B., and McKiernan, A.W., 2008. Evaluation of factors controlling smectite transformation and fluid production in subduction zones: application to the Nankai Trough. Island Arc, 17(2):208230. http://dx.doi.org/10.1111/j.1440-

1738.2008.00614.x

Screaton, E.J., Kimura, G., Curewitz, D., and the Expedition 316 Scientists, 2009. Expedition 316 summary. In Kinoshita, M., Tobin, H., Ashi, J., Kimura, G., Lallemant, S., Screaton, E.J., Curewitz, D., Masago, H., Moe, K.T., and the Expedition 314/315/316 Scientists, Proceedings of the Integrated Ocean Drilling Program, 314/315/ 316: Washington, DC (Integrated Ocean Drilling Program Management International, Inc.). http:// dx.doi.org/10.2204/iodp.proc.314315316.131.2009

Shipboard Scientific Party, 1991. Site 808. In Taira, A., Hill, I., Firth, J.V., et al., Proceedings of the Ocean Drilling Program, Initial Reports, 131: College Station, TX (Ocean Drilling Program), 71-269. http://dx.doi.org/10.2973/ odp.proc.ir.131.106.1991

Shipboard Scientific Party, 2001. Leg 190 summary. In Moore, G.F., Taira, A., Klaus, A., et al., Proceedings of the Ocean Drilling Program, Initial Reports, 190: College Station, TX (Ocean Drilling Program), 1-87. http:// dx.doi.org/10.2973/odp.proc.ir.190.101.2001

Srodon, J., Drits, V.A., McCarty, D.K., Hsieh, J.C.C., and Eberl, D.D., 2001. Quantitative X-ray diffraction analysis of clay-bearing rocks from random preparations. Clays and Clay Minerals, 49(6):514-528. http:// ccm.geoscienceworld.org/cgi/content/abstract/49/ $6 / 514$

Steurer, J.F., and Underwood, M.B., 2003. Clay mineralogy of mudstones from the Nankai Trough reference Sites 1173 and 1177 and frontal accretionary prism Site 1174. In Mikada, H., Moore, G.F., Taira, A., Becker, K., Moore, J.C., and Klaus, A. (Eds.), Proceedings of the Ocean Drilling Program, Scientific Results, 190/196: College Station, TX (Ocean Drilling Program), 1-37. http://dx.doi.org/ 10.2973/odp.proc.sr.190196.211.2003

Strasser, M., Dugan, B., Kanagawa, K., Moore, G.F., Toczko, S., Maeda, L., Kido, Y., Moe, K.T., Sanada, Y., Esteban, L., Fabbri, O., Geersen, J., Hammerschmidt, S., Hayashi, H., Heirman, K., Hüpers, A., Jurado Rodriguez, M.J., Kameo, K., Kanamatsu, T., Kitajima, H., Masuda, H., Milliken, K., Mishra, R., Motoyama, I., Olcott, K., Oohashi, K., Pickering, K.T., Ramirez, S.G., Rashid, H., Sawyer, D., Schleicher, A., Shan, Y., Skarbek, R., Song, I., Takeshita, T., Toki, T., Tudge, J., Webb, S., Wilson, D.J., Wu, H.-Y., and Yamaguchi, A., 2014a. Expedition 338 summary. In Strasser, M., Dugan, B., Kanagawa, K., Moore, G.F., Toczko, S., Maeda, L., and the Expedition 338 Scientists, Proceedings of the Integrated Ocean Drilling Program, 338: Yokohama (Integrated Ocean Drilling Program). http:// dx.doi.org/10.2204/iodp.proc.338.101.2014 
Strasser, M., Dugan, B., Kanagawa, K., Moore, G.F., Toczko, S., Maeda, L., Kido, Y., Moe, K.T., Sanada, Y., Esteban, L., Fabbri, O., Geersen, J., Hammerschmidt, S., Hayashi, H., Heirman, K., Hüpers, A., Jurado Rodriguez, M.J., Kameo, K., Kanamatsu, T., Kitajima, H., Masuda, H., Milliken, K., Mishra, R., Motoyama, I., Olcott, K., Oohashi, K., Pickering, K.T., Ramirez, S.G., Rashid, H., Sawyer, D., Schleicher, A., Shan, Y., Skarbek, R., Song, I., Takeshita, T., Toki, T., Tudge, J., Webb, S., Wilson, D.J., Wu, H.-Y., and Yamaguchi, A., 2014b. Site C0002. In Strasser, M., Dugan, B., Kanagawa, K., Moore, G.F., Toczko, S., Maeda, L., and the Expedition 338 Scientists, Proceedings of the Integrated Ocean Drilling Program, 338: Yokohama (Integrated Ocean Drilling Program). http://

dx.doi.org/10.2204/iodp.proc.338.103.2014

Tobin, H., Hirose, T., Saffer, D., Toczko, S., Maeda, L., Kubo, Y., Boston, B., Broderick, A., Brown, K., Crespo-Blanc, A., Even, E., Fuchida, S., Fukuchi, R., Hammerschmidt, S., Henry, P., Josh, M., Jurado, M.J., Kitajima, H., Kitamura, M., Maia, A., Otsubo, M., Sample, J., Schleicher, A., Sone, H., Song, C., Valdez, R., Yamamoto, Y., Yang, K., Sanada, Y., Kido, Y., and Hamada, Y., 2015a. Expedition 348 summary. In Tobin, H., Hirose, T., Saffer, D., Toczko, S., Maeda, L., Kubo, Y., and the Expedition 348 Scientists, Proceedings of the Integrated Ocean Drilling Program, 348: College Station, TX (Integrated Ocean Drilling Program). http://dx.doi.org/10.2204/ iodp.proc.348.101.2015

Tobin, H., Hirose, T., Saffer, D., Toczko, S., Maeda, L., Kubo, Y., Boston, B., Broderick, A., Brown, K., Crespo-Blanc, A., Even, E., Fuchida, S., Fukuchi, R., Hammerschmidt, S., Henry, P., Josh, M., Jurado, M.J., Kitajima, H., Kitamura, M., Maia, A., Otsubo, M., Sample, J., Schleicher, A., Sone, H., Song, C., Valdez, R., Yamamoto, Y., Yang, K., Sanada, Y., Kido, Y., and Hamada, Y., 2015b. Site C0002. In Tobin, H., Hirose, T., Saffer, D., Toczko, S., Maeda, L., Kubo, Y., and the Expedition 348 Scientists, Proceedings of the Integrated Ocean Drilling Program, 348: College Station, TX (Integrated Ocean Drilling Program). http://dx.doi.org/10.2204/

iodp.proc.348.103.2015

Tobin, H., Kinoshita, M., Ashi, J., Lallemant, S., Kimura, G., Screaton, E.J., Moe, K.T., Masago, H., Curewitz, D., and the Expedition 314/315/316 Scientists, 2009. NanTroSEIZE Stage 1 expeditions: introduction and synthesis of key results. In Kinoshita, M., Tobin, H., Ashi, J., Kimura, G., Lallemant, S., Screaton, E.J., Curewitz, D., Masago, H., Moe, K.T., and the Expedition 314/315/316 Scientists, Proceedings of the Integrated Ocean Drilling Program, 314/315/316: Washington, DC (Integrated Ocean Drilling Program Management International, Inc.). http://dx.doi.org/10.2204/ iodp.proc.314315316.101.2009

Underwood, M.B., Basu, N., Steurer, J., and Udas, S., 2003. Data report: normalization factors for semiquantitative X-ray diffraction analysis, with application to DSDP Site 297, Shikoku Basin. In Mikada, H., Moore, G.F., Taira, A., Becker, K., Moore, J.C., and Klaus, A. (Eds.), Proceedings of the Ocean Drilling Program, Scientific Results, 190/
196: College Station, TX (Ocean Drilling Program), 128. http://dx.doi.org/10.2973/

odp.proc.sr.190196.203.2003

Underwood, M.B., and Guo, J., 2013. Data report: clay mineral assemblages in the Shikoku Basin, NanTroSEIZE subduction inputs, IODP Sites C0011 and C0012. In Saito, S., Underwood, M.B., Kubo, Y., and the Expedition 322 Scientists, Proceedings of the Integrated Ocean Drilling Program, 322: Tokyo (Integrated Ocean Drilling Program Management International, Inc.). http:// dx.doi.org/10.2204/iodp.proc.322.202.2013

Underwood, M.B., Orr, R., Pickering, K., and Taira, A., 1993a. Provenance and dispersal patterns of sediments in the turbidite wedge of Nankai Trough. In Hill, I.A., Taira, A., Firth, J.V., et al., Proceedings of the Ocean Drilling Program, Scientific Results, 131: College Station, TX (Ocean Drilling Program), 15-34. http://dx.doi.org/ 10.2973/odp.proc.sr.131.105.1993

Underwood, M.B., Pickering, K., Gieskes, J.M., Kastner, M., and Orr, R., 1993b. Sediment geochemistry, clay mineralogy, and diagenesis: a synthesis of data from Leg 131, Nankai Trough. In Hill, I.A., Taira, A., Firth, J.V., et al., Proceedings of the Ocean Drilling Program, Scientific Results, 131: College Station, TX (Ocean Drilling Program), 343-363. http://dx.doi.org/10.2973/ odp.proc.sr.131.137.1993

Underwood, M.B., Saito, S., Kubo, Y., and the Expedition 322 Scientists, 2010. Expedition 322 summary. In Saito, S., Underwood, M.B., Kubo, Y., and the Expedition 322 Scientists, Proceedings of the Integrated Ocean Drilling Program, 322: Tokyo (Integrated Ocean Drilling Program Management International, Inc.). http://dx.doi.org/ 10.2204/iodp.proc.322.101.2010

Underwood, M.B., and Song, C., 2016. Data report: clay mineral assemblages in cuttings from Hole C0002F, IODP Expedition 338, upper Nankai Trough accretionary prism. In Strasser, M., Dugan, B., Kanagawa, K., Moore, G.F., Toczko, S., Maeda, L., and the Expedition 338 Scientists, Proceedings of the Integrated Ocean Drilling Program, 338: Yokohama (Integrated Ocean Drilling Program). http://dx.doi.org/10.2204/ iodp.proc.338.206.2016

Underwood, M.B., and Steurer, J.F., 2003. Composition and sources of clay from the trench slope and shallow accretionary prism of Nankai Trough. In Mikada, H., Moore, G.F., Taira, A., Becker, K., Moore, J.C., and Klaus, A. (Eds.), Proceedings of the Ocean Drilling Program, Scientific Results, 190/196: College Station, TX (Ocean Drilling Program), 1-28. http://dx.doi.org/10.2973/ odp.proc.sr.190196.206.2003

Warr, L.N., and Mählmann, R.F., 2015. Recommendations for Kübler Index standardization. Clay Minerals, 50(3):283-286. http://dx.doi.org/10.1180/clay$\min .2015 .050 .3 .02$

Initial receipt: 20 April 2016

Acceptance: 18 November 2016

Publication: 22 February 2017

MS 348-203 
Figure F1. Map of the Nankai Trough and Kumano Basin study area (NanTroSEIZE transect) showing locations of IODP drill sites C0002, C0011, and C0012. The composition of sediment at Site C0002 is compared to coeval (late Miocene) deposits at Sites C0011 and C0012.

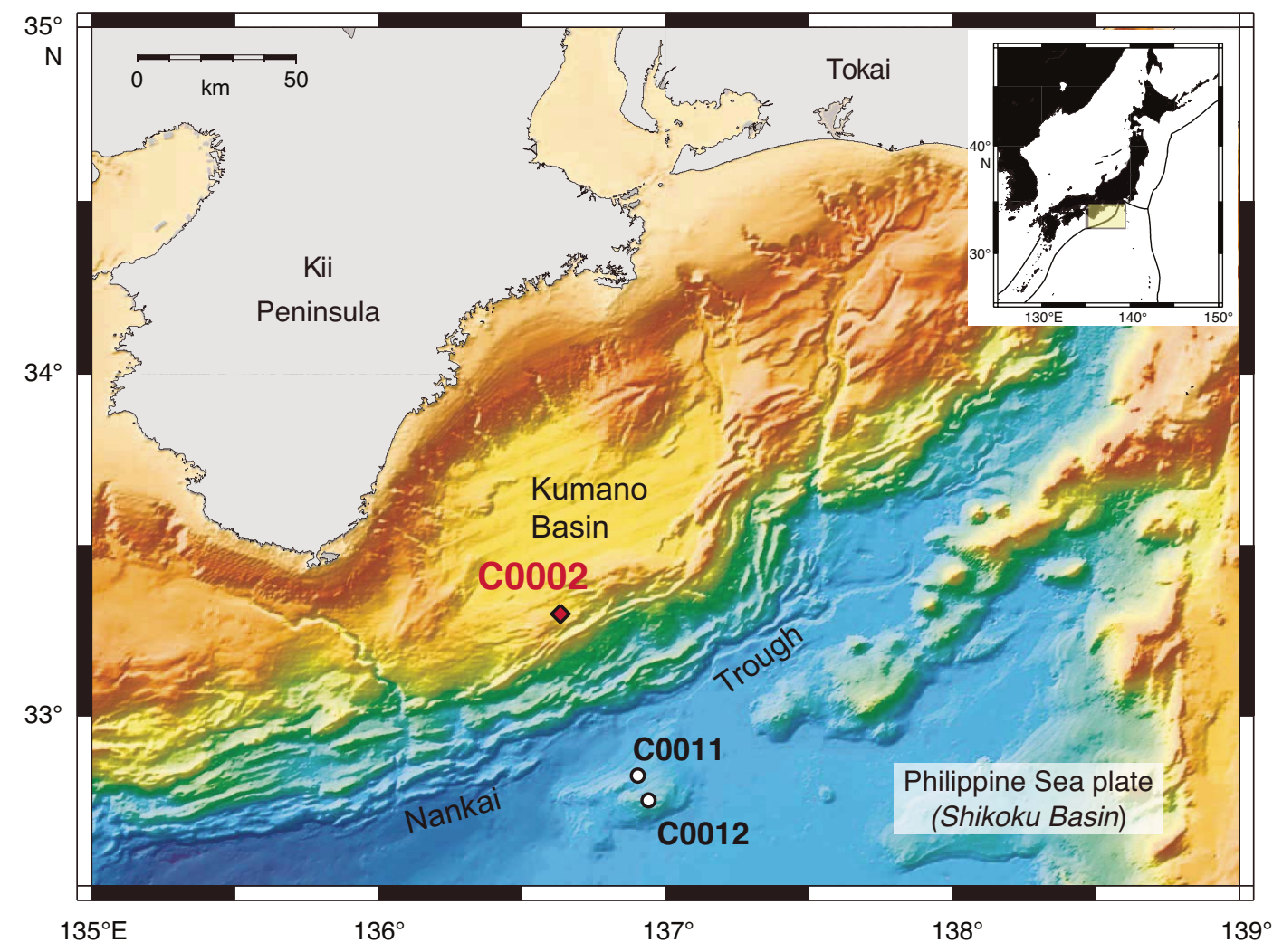


Figure F2. Seismic in-line section crossing the Kumano Basin showing location of Site C0002 and lithologic units defined by shipboard analyses of cores and cuttings (see the "Expedition 348 summary" chapter [Tobin et al., 2015a]). LWD = logging while drilling, $\mathrm{VE}=$ vertical exaggeration.

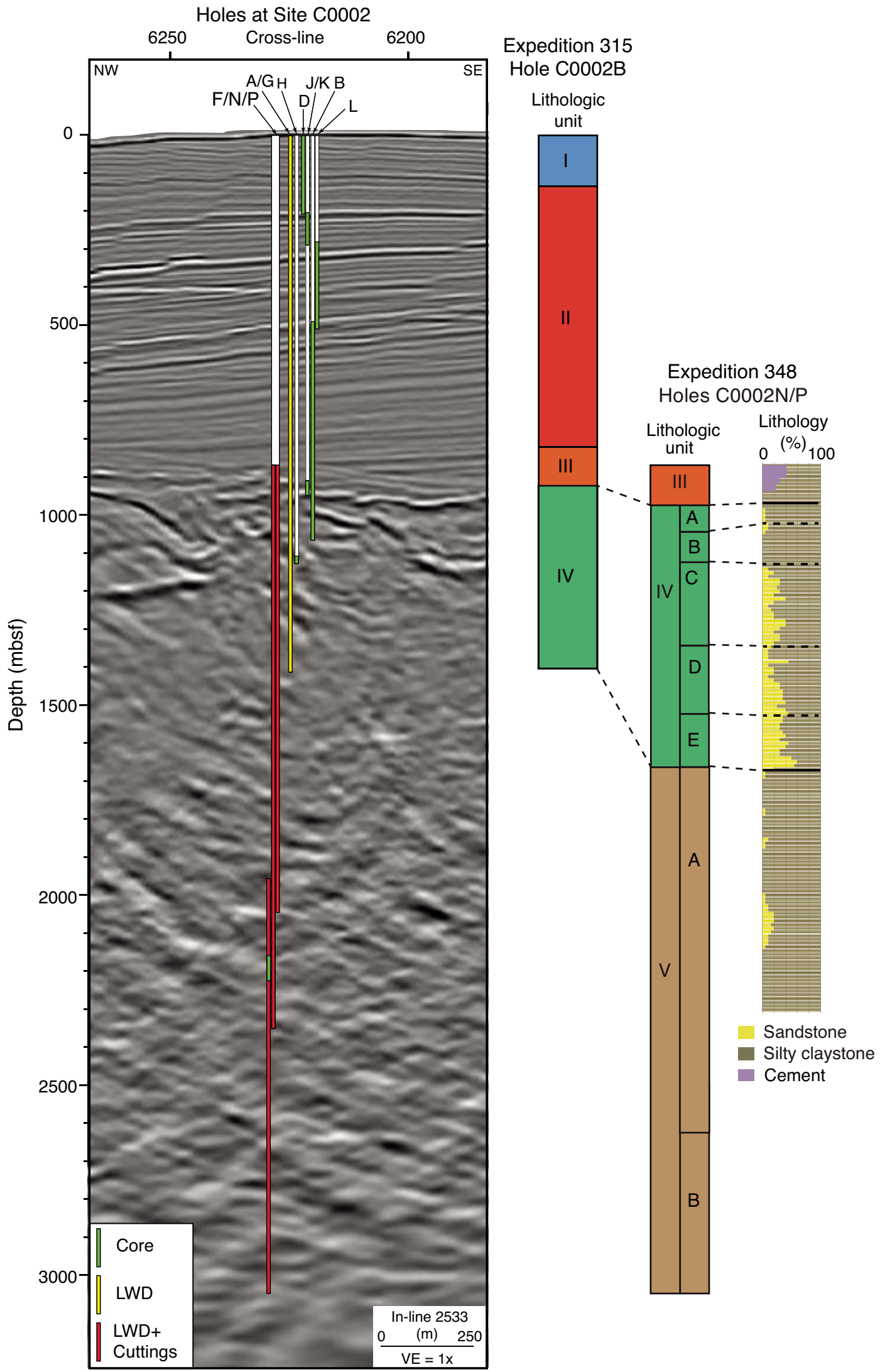


Figure F3. Correlation of lithologic units and unit boundaries from Holes C0002F and C0002N. Stratigraphic summary is from "Expedition 348 summary" chapter [Tobin et al., 2015a]).

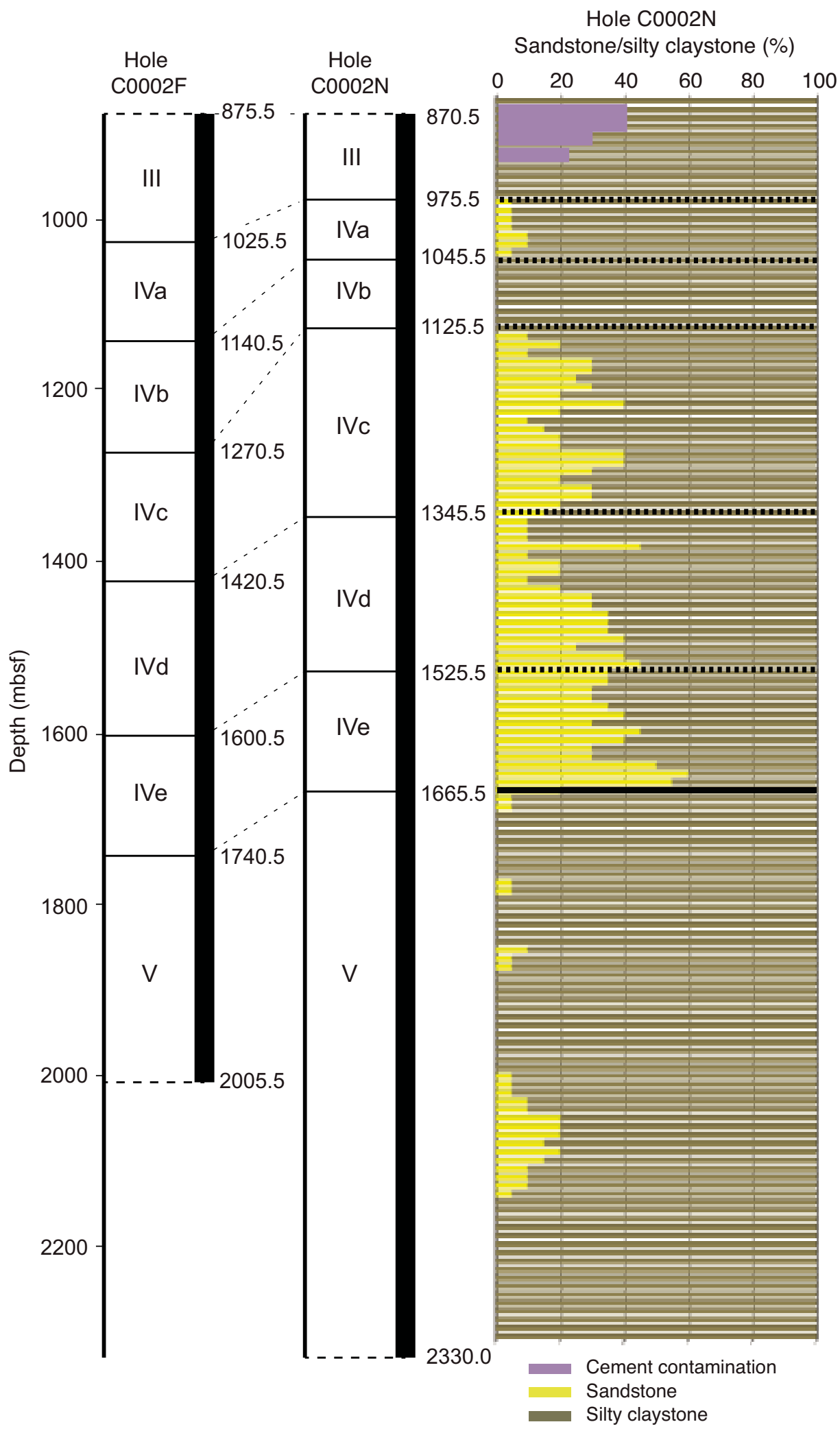


Figure F4. Calculated abundances (wt \%) of smectite, illite, chlorite, kaolinite, and quartz within the clay-size fraction of cuttings (1-4 mm diameter) from Hole C0002F (open symbols; data from Underwood and Song, 2016) and Hole C0002N (solid symbols; this report). Stratigraphic summary is from the "Expedition 348 summary" chapter (Tobin et al., 2015a).

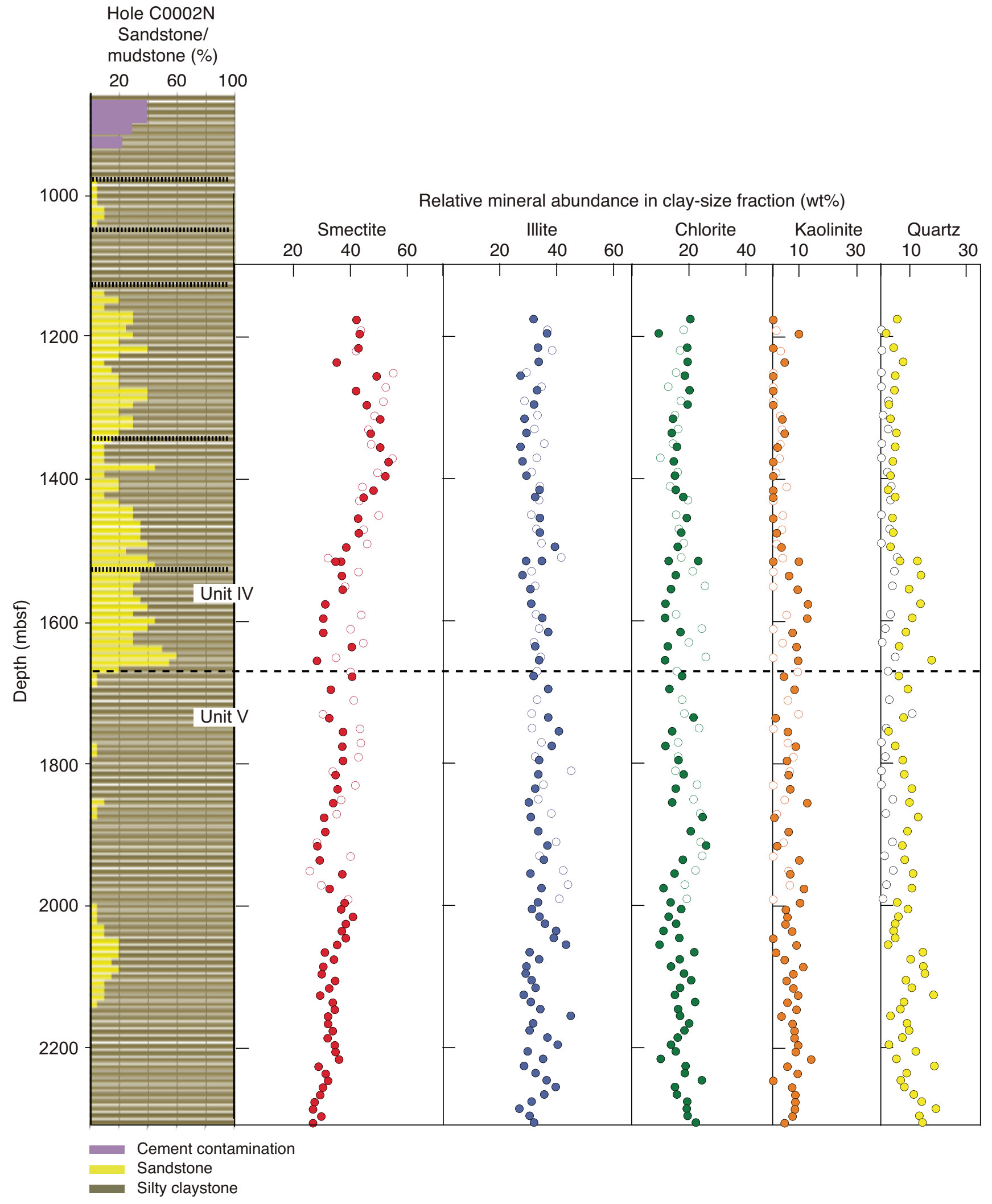


Figure F5. Calculated abundances (wt \%) of total clay minerals, smectite, illite, and undifferentiated chlorite + kaolinite within bulk sediment cuttings (1-4 mm) from Hole C0002F (open symbols; data from Underwood and Song, 2016) and Hole C0002N (solid symbols; this report). Values for total clay minerals are from shipboard measurements (Strasser et al., 2014b; see the "Site C0002" chapter [Tobin et al., 2015b]). Stratigraphic summary is from the "Expedition 348 summary" chapter (Tobin et al., 2015a).

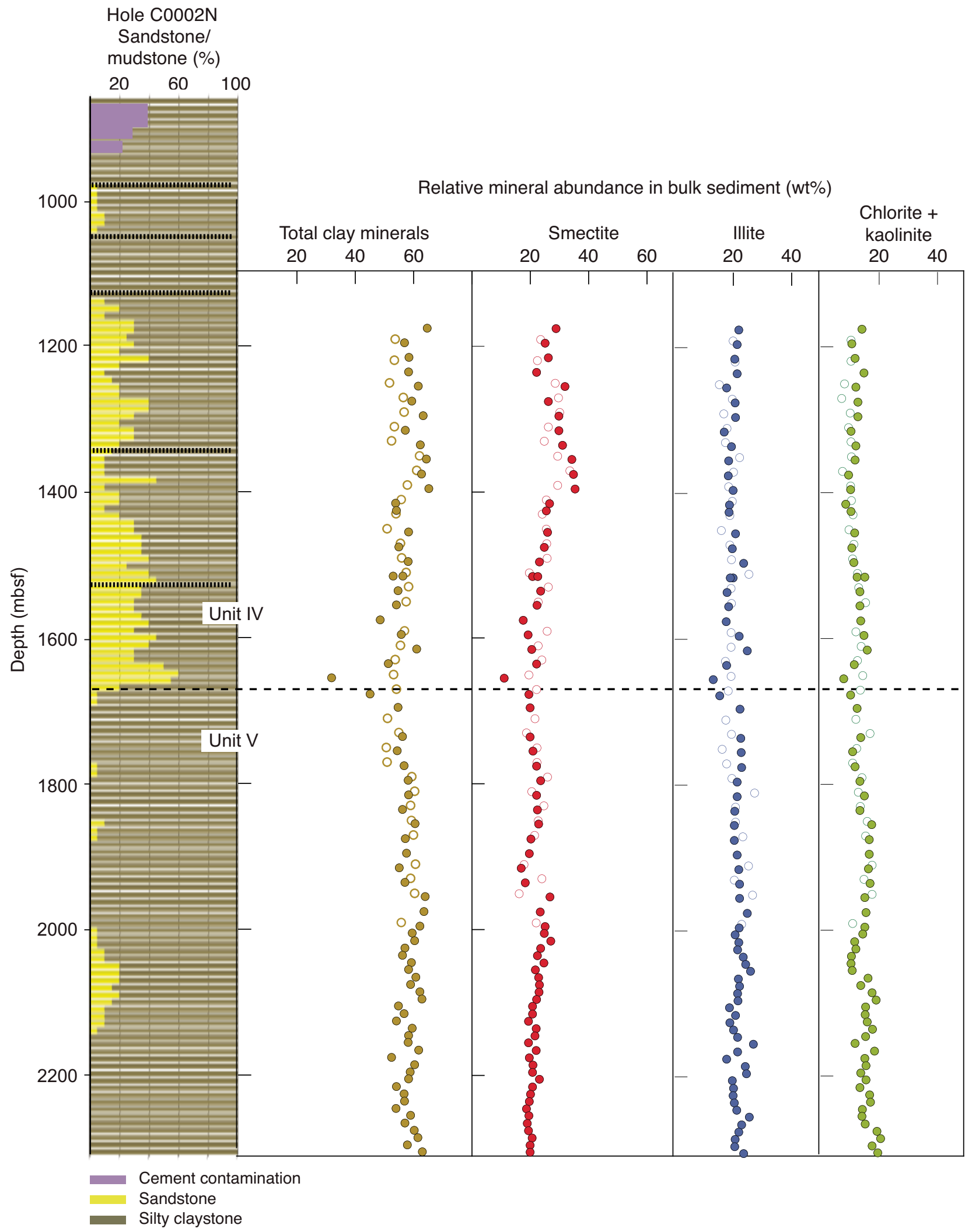


Figure F6. llite/smectite (I/S) expandability, illite abundance in I/S mixed-layer clay, and illite crystallinity index within the clay-size fraction of cuttings $(1-4 \mathrm{~mm}$ ) from Hole C0002F (open symbols; data from Underwood and Song, 2016) and Hole C0002N (solid symbols; this report). Dashed trend lines are qualitative. Boundaries for anchizone and epizone metamorphism are from Warr and Mählmann (2015).

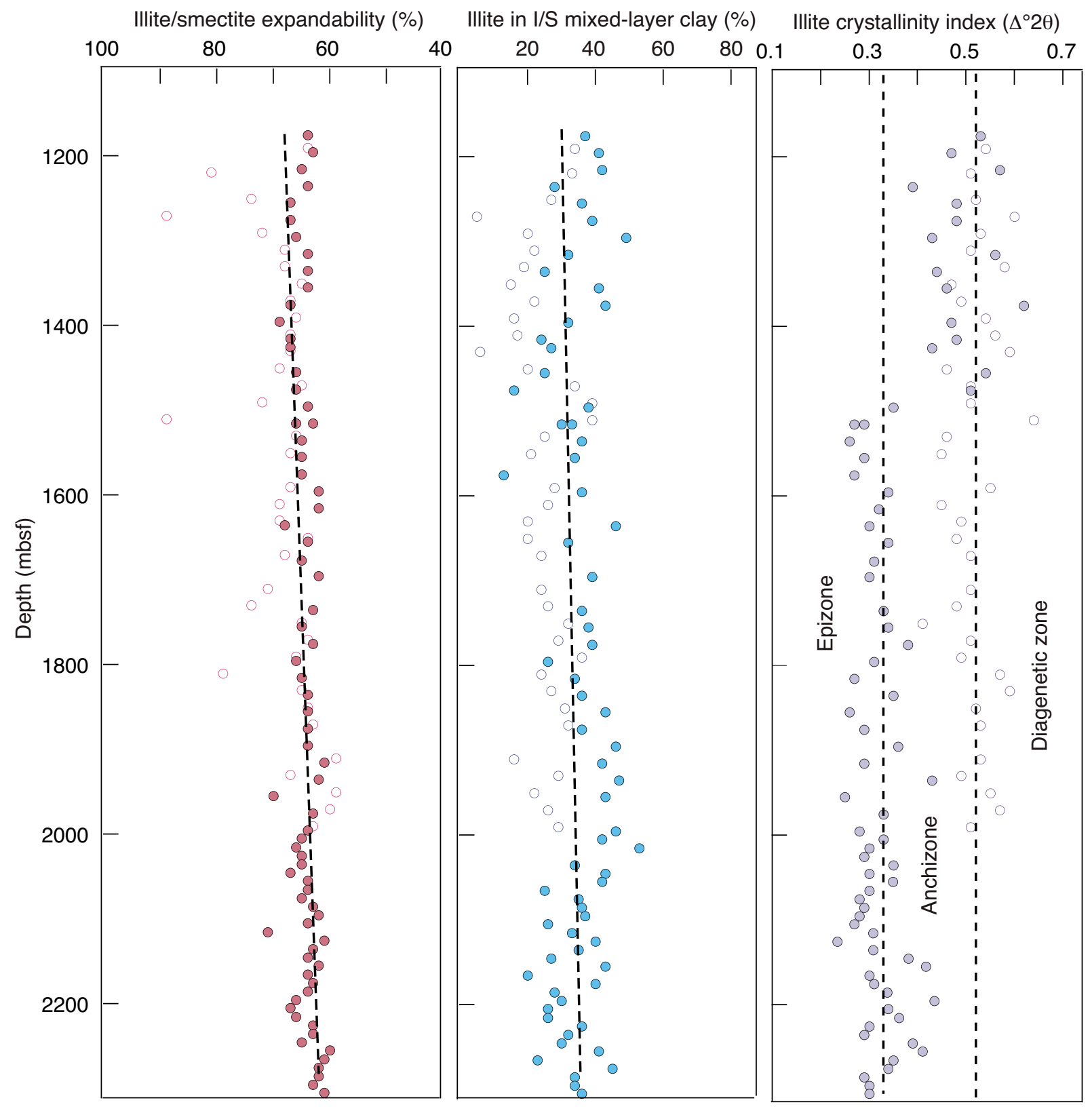


Table T1. Matrix of normalization factors derived from singular value decomposition and analysis of standard mineral mixtures, used to calculate relative mineral abundances in clay-size aggregates, Hole C0002N.

\begin{tabular}{lrrrr}
\hline \multirow{2}{*}{$\begin{array}{c}\text { Influencing } \\
\text { mineral }\end{array}$} & \multicolumn{4}{c}{ Target mineral in standard mixture } \\
\cline { 2 - 5 } & \multicolumn{1}{c}{ Smectite } & \multicolumn{1}{c}{ lllite } & \multicolumn{1}{c}{ Chlorite } & \multicolumn{1}{c}{ Quartz } \\
\hline Smectite & $7.4475294 \mathrm{E}-04$ & $-3.1953641 \mathrm{E}-05$ & $-7.5067212 \mathrm{E}-05$ & $-1.5661915 \mathrm{E}-04$ \\
Illite & $6.3114654 \mathrm{E}-05$ & $3.7866938 \mathrm{E}-03$ & $8.4222964 \mathrm{E}-05$ & $1.1769286 \mathrm{E}-04$ \\
Chlorite & $-3.5636057 \mathrm{E}-04$ & $-6.7378140 \mathrm{E}-05$ & $2.5121504 \mathrm{E}-03$ & $5.2290707 \mathrm{E}-05$ \\
Quartz & $9.3573136 \mathrm{E}-03$ & $3.6491468 \mathrm{E}-03$ & $3.2755411 \mathrm{E}-03$ & $1.4825645 \mathrm{E}-02$ \\
\hline
\end{tabular}

Table T2. Results of X-ray diffraction analyses $(<2 \mu \mathrm{m}$ size fraction) for cuttings samples $(1-4 \mathrm{~mm})$, Hole C0002N. (Continued on next page.)

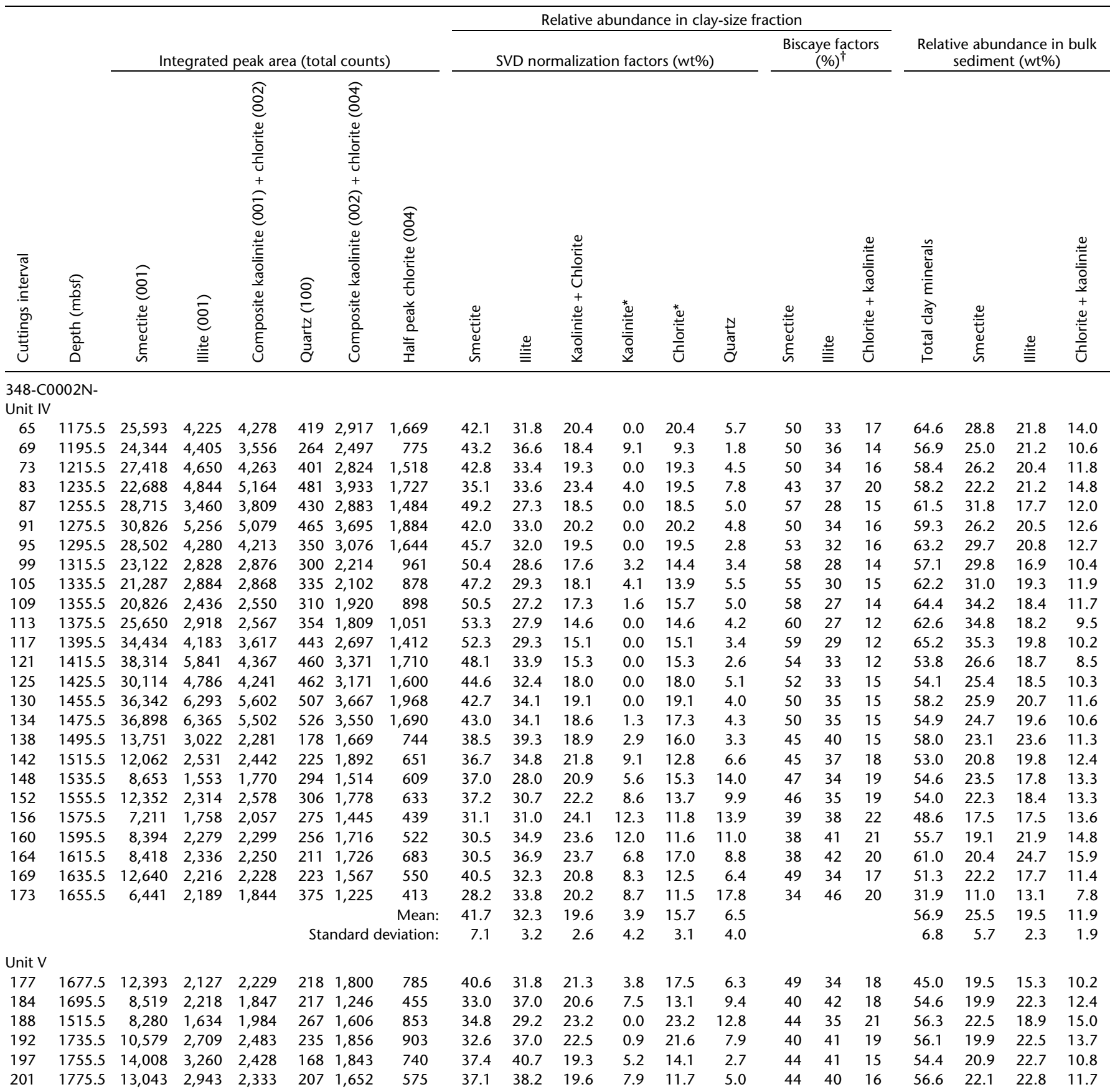


Table T2 (continued).

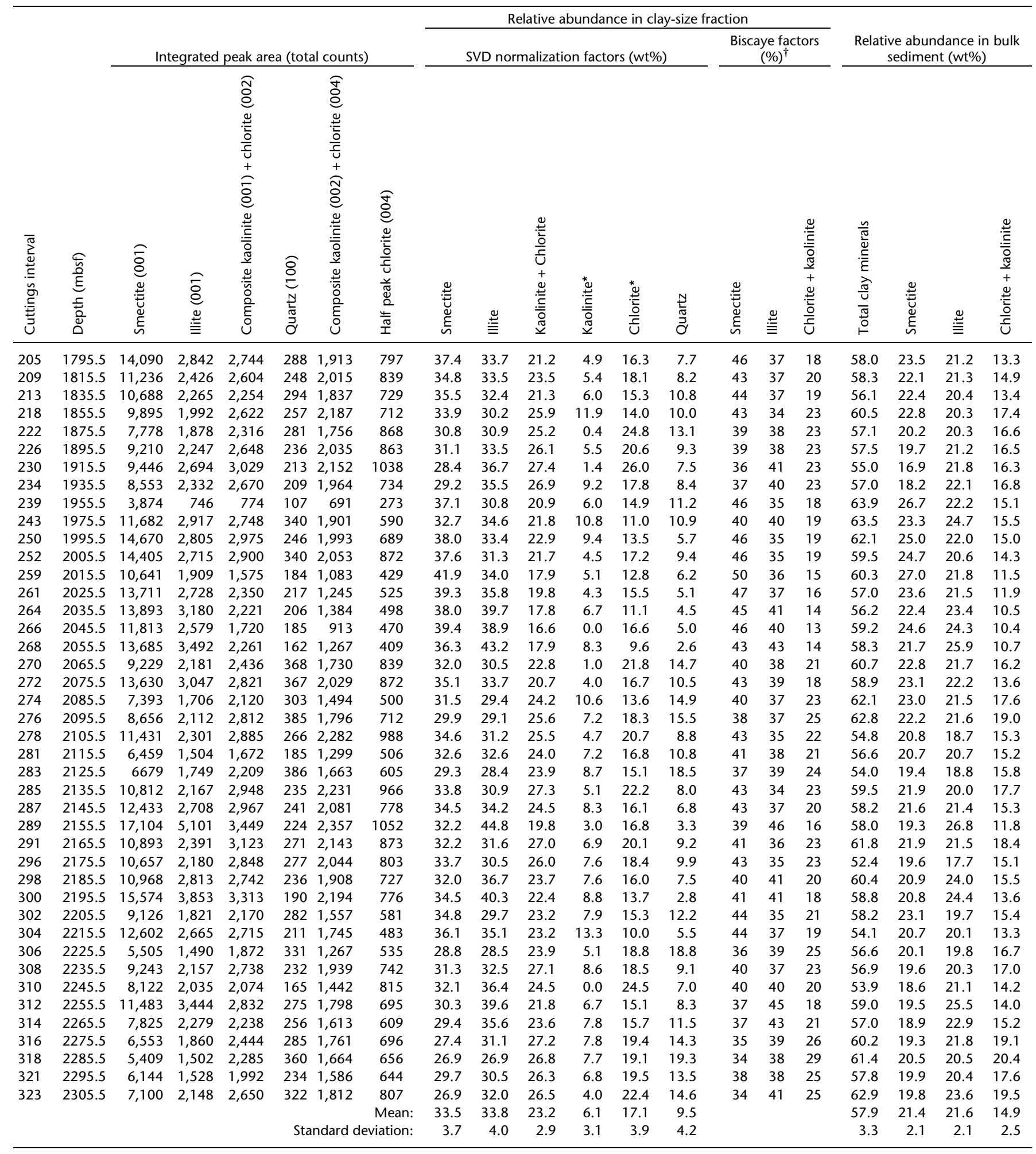

* = proportions of kaolinite and chlorite use ratio from Guo and Underwood (2011) method and SVD results for undifferentiated chlorite (002) + kaolinite (001). $\dagger=$ Biscaye (1965) weighting factors are $1 \times$ smectite (001), $4 \times$ illite (001), and $2 \times$ undifferentiated chlorite (002) + kaolinite (001). SVD = singular value decomposition. 
Table T3. Illite/smectite expandability values, illite abundance in illite/smectite (I/S) mixed-layer clay, and illite crystallinity index $(<2 \mu \mathrm{m}$ size fraction) for cuttings samples $(1-4 \mathrm{~mm})$, Hole C0002N. (Continued on next page.)

\begin{tabular}{|c|c|c|c|c|c|c|c|c|}
\hline $\begin{array}{l}\text { Cuttings } \\
\text { interval }(N)\end{array}$ & $\begin{array}{l}\text { Depth } \\
\text { (mbsf) }\end{array}$ & $\begin{array}{c}\text { Smectite (001) } \\
\text { saddle (cps) }\end{array}$ & $\begin{array}{c}\text { Smectite (001) } \\
\text { peak (cps) }\end{array}$ & $\begin{array}{l}\text { Saddle: } \\
\text { peak ratio }\end{array}$ & $\begin{array}{c}\text { Expandability } \\
(\%)\end{array}$ & $\begin{array}{c}\text { Illite }(002)+ \\
\text { smectite }(003) \\
\left({ }^{\circ} 2 \theta\right)\end{array}$ & $\begin{array}{c}\text { Illite in I/S } \\
(\%)\end{array}$ & $\begin{array}{l}\text { Illite crystallinity } \\
\text { index }\left(\Delta^{\circ} 2 \theta\right)\end{array}$ \\
\hline \multicolumn{9}{|c|}{$\begin{array}{l}\text { 348-C0002N- } \\
\text { Unit IV }\end{array}$} \\
\hline 65 & 1175.5 & 208 & 317 & 0.66 & 64 & 16.10 & 37 & 0.53 \\
\hline 69 & 1195.5 & 210 & 311 & 0.68 & 63 & 16.15 & 41 & 0.47 \\
\hline 73 & 1215.5 & 213 & 333 & 0.64 & 65 & 16.17 & 42 & 0.57 \\
\hline 83 & 1235.5 & 184 & 275 & 0.67 & 64 & 15.98 & 28 & 0.39 \\
\hline 87 & 1255.5 & 172 & 299 & 0.58 & 67 & 16.09 & 36 & 0.48 \\
\hline 91 & 1275.5 & 210 & 353 & 0.59 & 67 & 16.13 & 39 & 0.48 \\
\hline 95 & 1295.5 & 182 & 297 & 0.61 & 66 & 16.29 & 49 & 0.43 \\
\hline 99 & 1315.5 & 179 & 276 & 0.65 & 64 & 16.03 & 32 & 0.56 \\
\hline 105 & 1335.5 & 166 & 251 & 0.66 & 64 & 15.95 & 25 & 0.44 \\
\hline 109 & 1355.5 & 169 & 253 & 0.67 & 64 & 16.15 & 41 & 0.46 \\
\hline 113 & 1375.5 & 176 & 299 & 0.59 & 67 & 16.18 & 43 & 0.62 \\
\hline 117 & 1395.5 & 203 & 368 & 0.55 & 69 & 16.03 & 32 & 0.47 \\
\hline 121 & 1415.5 & 262 & 449 & 0.58 & 67 & 15.93 & 24 & 0.48 \\
\hline 125 & 1425.5 & 208 & 351 & 0.59 & 67 & 15.97 & 27 & 0.43 \\
\hline 130 & 1455.5 & 271 & 441 & 0.61 & 66 & 15.95 & 25 & 0.54 \\
\hline 134 & 1475.5 & 278 & 452 & 0.62 & 66 & 15.85 & 16 & 0.51 \\
\hline 138 & 1495.5 & 114 & 173 & 0.66 & 64 & 16.11 & 38 & 0.35 \\
\hline 142 & 1515.5 & 104 & 154 & 0.68 & 63 & 16.01 & 30 & 0.29 \\
\hline 148 & 1535.5 & 72 & 112 & 0.64 & 65 & 16.09 & 36 & 0.26 \\
\hline 152 & 1555.5 & 100 & 159 & 0.63 & 65 & 16.06 & 34 & 0.29 \\
\hline 156 & 1575.5 & 72 & 114 & 0.63 & 65 & 15.82 & 13 & 0.27 \\
\hline 160 & 1595.5 & 86 & 122 & 0.70 & 62 & 16.08 & 36 & 0.34 \\
\hline 164 & 1615.5 & 94 & 131 & 0.72 & 62 & - & & 0.32 \\
\hline 169 & 1635.5 & 93 & 163 & 0.57 & 68 & 16.23 & 46 & 0.30 \\
\hline 173 & 1655.5 & 67 & 100 & 0.67 & 64 & 16.03 & 32 & 0.34 \\
\hline \multicolumn{9}{|l|}{ Unit V } \\
\hline 177 & 1677.5 & 99 & 156 & 0.63 & 65 & - & & 0.31 \\
\hline 184 & 1695.5 & 84 & 120 & 0.70 & 62 & 16.13 & 39 & 0.30 \\
\hline 188 & 1515.5 & 60 & 98 & 0.61 & 66 & 16.04 & 33 & 0.27 \\
\hline 192 & 1735.5 & 99 & 143 & 0.69 & 63 & 16.09 & 36 & 0.33 \\
\hline 197 & 1755.5 & 122 & 191 & 0.64 & 65 & 16.11 & 38 & 0.34 \\
\hline 201 & 1775.5 & 118 & 171 & 0.69 & 63 & 16.12 & 39 & 0.38 \\
\hline 205 & 1795.5 & 116 & 189 & 0.61 & 66 & 15.96 & 26 & 0.31 \\
\hline 209 & 1815.5 & 99 & 154 & 0.64 & 65 & 16.06 & 34 & 0.27 \\
\hline 213 & 1835.5 & 101 & 151 & 0.67 & 64 & 16.08 & 36 & 0.35 \\
\hline 218 & 1855.5 & 83 & 126 & 0.66 & 64 & 16.18 & 43 & 0.26 \\
\hline 222 & 1875.5 & 75 & 112 & 0.67 & 64 & 16.09 & 36 & 0.29 \\
\hline 226 & 1895.5 & 89 & 134 & 0.66 & 64 & 16.24 & 46 & 0.36 \\
\hline 230 & 1915.5 & 106 & 144 & 0.74 & 61 & 16.17 & 42 & 0.29 \\
\hline 234 & 1935.5 & 82 & 116 & 0.71 & 62 & 16.26 & 47 & 0.43 \\
\hline 239 & 1955.5 & 23 & 45 & 0.51 & 70 & 16.18 & 43 & 0.25 \\
\hline 243 & 1975.5 & 108 & 158 & 0.68 & 63 & - & & 0.33 \\
\hline 250 & 1995.5 & 118 & 179 & 0.66 & 64 & 16.23 & 46 & 0.28 \\
\hline 252 & 2005.5 & 111 & 172 & 0.65 & 65 & 16.17 & 42 & 0.33 \\
\hline 259 & 2015.5 & 87 & 144 & 0.60 & 66 & 16.37 & 53 & 0.30 \\
\hline 261 & 2025.5 & 111 & 177 & 0.63 & 65 & - & & 0.29 \\
\hline 264 & 2035.5 & 112 & 176 & 0.64 & 65 & 16.06 & 34 & 0.35 \\
\hline 266 & 2045.5 & 87 & 151 & 0.58 & 67 & 16.18 & 43 & 0.30 \\
\hline 268 & 2055.5 & 120 & 183 & 0.66 & 64 & 16.17 & 42 & 0.35 \\
\hline 270 & 2065.5 & 76 & 117 & 0.65 & 64 & 15.95 & 25 & 0.30 \\
\hline 272 & 2075.5 & 111 & 174 & 0.64 & 65 & 16.07 & 35 & 0.28 \\
\hline 274 & 2085.5 & 73 & 106 & 0.69 & 63 & 16.09 & 36 & 0.29 \\
\hline 276 & 2095.5 & 84 & 119 & 0.71 & 62 & 16.10 & 37 & 0.28 \\
\hline 278 & 2105.5 & 99 & 152 & 0.65 & 64 & 15.96 & 26 & 0.27 \\
\hline 281 & 2115.5 & 32 & 63 & 0.51 & 71 & 16.04 & 33 & 0.31 \\
\hline 283 & 2125.5 & 66 & 91 & 0.73 & 61 & 16.14 & 40 & 0.23 \\
\hline 285 & 2135.5 & 95 & 140 & 0.68 & 63 & 16.07 & 35 & 0.31 \\
\hline 287 & 2145.5 & 118 & 180 & 0.66 & 64 & 15.97 & 27 & 0.38 \\
\hline 289 & 2155.5 & 157 & 224 & 0.70 & 62 & 16.19 & 43 & 0.42 \\
\hline 291 & 2165.5 & 103 & 159 & 0.65 & 64 & 15.89 & 20 & 0.30 \\
\hline 296 & 2175.5 & 97 & 140 & 0.69 & 63 & 16.14 & 40 & 0.31 \\
\hline 298 & 2185.5 & 106 & 158 & 0.67 & 64 & 15.98 & 28 & 0.34 \\
\hline 300 & 2195.5 & 129 & 210 & 0.61 & 66 & 16.00 & 30 & 0.44 \\
\hline
\end{tabular}


Table T3 (continued).

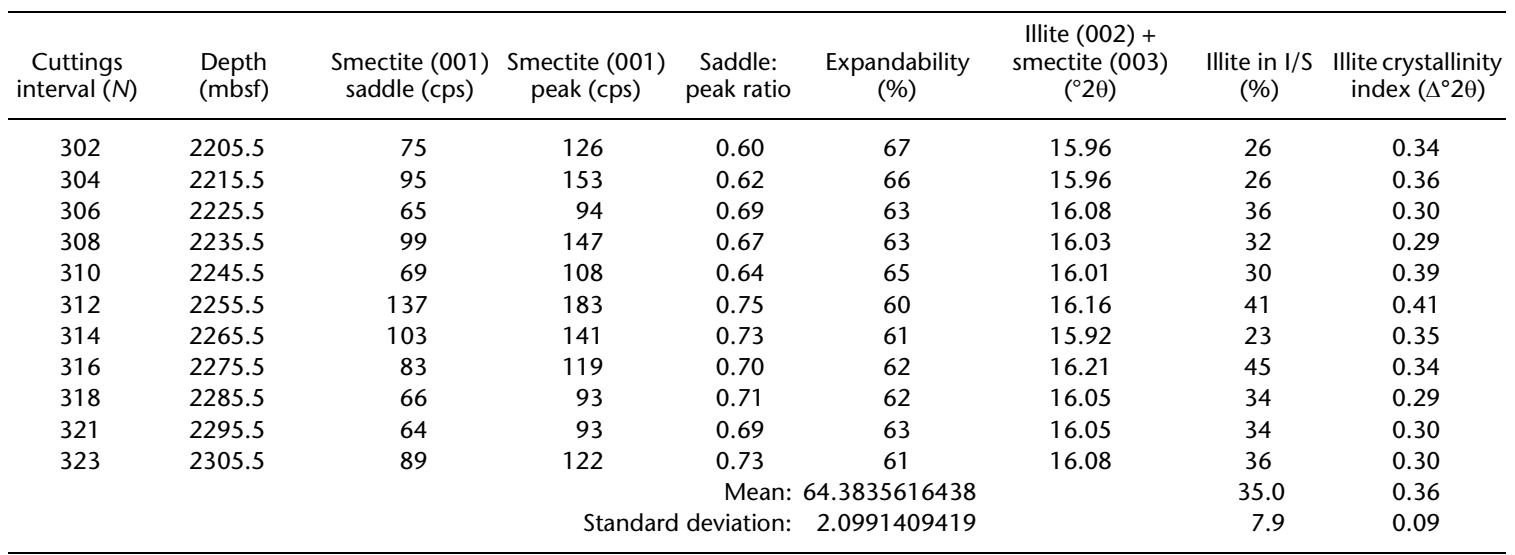

cps $=$ counts per step, $-=$ peak intensity too low to resolve position of center. 